\title{
AFFORESTATION AS A TYPE OF PEATLAND RECULTIVATION AND ASSESSMENT OF ITS AFFECTING FACTORS IN THE REDUCTION OF GHG EMISSIONS
}

Emīls Mārtiṇš UPENIEKS, Latvian State Forest Research Institute "Silava", Rigas iela 111, LV-2169 Salaspils, Latvia, emilsmartinsupenieks@gmail.com (corresponding author)

Agnese RUDUSĀNE, University of Latvia, Jelgavas iela 1, LV-1004 Riga, Latvia, agnese.rudusane@inbox.lv

\begin{abstract}
Peatlands play a significant role in the regulation of greenhouse gasses (GHG) by sequestrating carbon from the atmosphere. Unsustainable peat extraction can lead to an increase in GHG emissions. It is important to recultivate the peatland after the extraction of peat so that it does not become an emitter but remains a carbon sink and sequestrator. One of the most effective and suitable types of recultivation in Latvia that also has a positive effect on GHG circulation is afforestation.

The aim of the study is to describe afforestation as a type of recultivation and to evaluate its influencing factors in the reduction of GHG emissions in peatlands.

The study analyzed the data obtained in the LIFE REstore project which contains measurements of the three main $\mathrm{GHGs} \mathrm{CO}_{2}, \mathrm{CH}_{4}$ and $\mathrm{N}_{2} \mathrm{O}$ ) and the factors affecting them. The results show that in afforested areas the closest correlation with the amount of emitted $\mathrm{CO}_{2}$ out of all the analyzed factors is formed by soil temperature. As it increases, so do the $\mathrm{CO}_{2}$ emissions. As the depth of soil increases, the correlation between temperature and $\mathrm{CO}_{2}$ emissions becomes closer. In the study areas, regularities that would directly explain the relatively low amount of GHG emissions in the afforested areas were not found among the analyzed quantitative factors.
\end{abstract}

Keywords: afforestation, recultivation, carbon dioxide, methane, nitrous oxide, peat soils

\section{INTRODUCTION}

During 20th century the global average air temperature has been significantly rising at a rapid, unusual pace (Ji et al., 2014). The main reason for this is increasing concentration of greenhouse gases (GHG) in the atmosphere, which is caused by human activity (Ring et al., 2012). Three main human-caused GHGs are carbon dioxide $\left(\mathrm{CO}_{2}\right)$, methane $\left(\mathrm{CH}_{4}\right)$ and nitrous oxide $\left(\mathrm{N}_{2} \mathrm{O}\right)$ (NRDC, 2019). To reduce the impact of these gases on global climate change, it is important to plan human actions in such a way as to minimize the emissions of these gases, as well as to reduce their amount in the atmosphere. One way to reduce GHG emissions in the atmosphere is sustainable land management. This means rehabilitating the areas where resource extraction has been concluded so GHGs can be sequestrated into biomass and emissions reduced. This paper will focus on afforestation as one of the most effective ways of recultivating degraded peatlands in Latvia.

One of the biggest carbon sinks in the terrestrial biosphere are peatlands. Although peatlands cover only about $3 \%$ $\left(4,000,000 \mathrm{~km}^{2}\right)$ of the world's total land area, they store at least $550 \mathrm{Gt}$ of carbon in their peat soils, or $30 \%$ of all land-based carbon in the world (Parish et al., 2008). This high carbon concentration in peatlands is ensured by the wet conditions (Joosten, Couwenberg, 2009). Before peat extraction the peatland area is drained (Haghighi et al., 2018). As a result, the constant moisture conditions in the upper layer are disturbed and the $\mathrm{CO}_{2}$ balance becomes negative. In order to restore $\mathrm{CO}_{2}$ sequestration, after the completion of peat extraction, it is necessary to recultivate the area.

In LIFE REstore project it was concluded that afforestation is one of the most effective ways of peatland recultivation in Latvia to keep the GHG emissions low. In fact, $\mathrm{CO}_{2}$ emissions are even smaller than in the areas, where recultivation is done by restoring bog ecosystem (renaturalization). It was observed that renaturalized areas emit more $\mathrm{CH}_{4}$ than the afforested areas and $\mathrm{CO}_{2}$ emissions remain high during summer months, when groundwater level decreases. There was even a sink effect where Scots pine (Pinus sylvestris L.) was used for afforestation (Lazdiņ̌̌, Lupiḳis, 2019).

The first studies about GHG emissions from peatlands have been started only in the last decades of $20^{\text {th }}$ century however since the beginning of $21^{\text {st }}$ century the amount of research has been rising. The demand for these studies is dictated

Copyright (C) 2021 The Authors. Published by Vytautas Magnus University. This is an open-access article distributed under the terms of the Creative Commons Attribution License (CC BY 4.0), which permits unrestricted use, distribution, and reproduction in any medium, provided the original author and source are credited. 
by the European Green Deal, which proposes climate neutrality in the EU by 2050 (Krīgere, 2020). In Latvia comprehensive research related to GHG fluxes has been started within the scope of the "LIFE REstore" project carried out by the Nature Conservation Agency and its partners although a big portion of the collected data has not yet to be analyzed.

The aim of the study is to describe afforesting as a type of peatland recultivation and to evaluate its efficiency in GHG mitigation.

\section{RESEARCH METHODS}

The data used for paper was collected from two mires which were afforested after peat extraction - Kaigu and Silgulda mire (Figure 1). Different types of afforestation were studied: more than 20 years old pine and birch stands and an area which was afforested with various tree species which are fast-growing in the juvenile period (poplar Populus spp. v. Vesten, silver birch Betula pendula, black alder Alnus glutinosa and Scots pine Pinus sylvestris (Lazdina et al., 2019a)). Two areas were used for reference: one without vegetation and one with herbaceous and shrub vegetation.

In all the sample fields the main GHG emissions $\left(\mathrm{CO}_{2}, \mathrm{CH}_{4}\right.$ and $\left.\mathrm{N}_{2} \mathrm{O}\right)$ were measured. Also, measurements of the factors that affect them (air and soil temperatures at depths of 5, 10,15 and $30 \mathrm{~cm}$, water table depth, weather conditions at the time of the measurements, area of both the peatland and the part of it that is degraded, thickness of the remaining peat layer, degree of decomposition of the upper peat layer) were taken. Secondary data used for this paper were obtained in a 2year period during the LIFE REstore project from December 2016 to November 2018. The data was processed in Microsoft Excel, IBM SPCC Statistics 22, and PC-ORD 5.

\section{Study area}

Kaigu mire is located in Tīreḷu Plain which is a part of the Middle Latvian Lowland at the central part of Latvia. Area of the mire is 3,290 hectares, and the average depth of the peat layer is 8.5 meters (Krauklis, 1994). The slightly undulating terrain which can be found around the plain makes the necessary conditions for the formation of mires, as the runoff groundwater is disturbed (Kalnina, 2019). Peat extraction takes place in the whole area except for margins where peat layer is thinner and is not suited for extraction. Kaigu mire is a bog (Krauklis, 1994) therefore its main water source is rainfall and before extraction it was characterized by a dome-like shape with a slight increase in height from margins to center. Multiple parts of the peatland are being recultivated, for example a territory in the south is afforested (LGIA, 2016).

Silgulda mire is located in Adzele Rise which is a part of the East Latvian Lowland at the northeast part of Latvia. Area of the mire is 851 hectares, and the maximum depth of the peat layer is 5.5 meters. Peat extraction takes place in most of the mire's area. Silgulda mire is a bog (Krauklis, 1998). In the northern part of the bog is Lake Silgulda which entirely fits in the territory of the bog. Recultivation is carried out in the central, northern, and eastern parts of the bog. Afforested areas have trees of different productivity which results in an uneven tree canopy (LGIA, 2016).

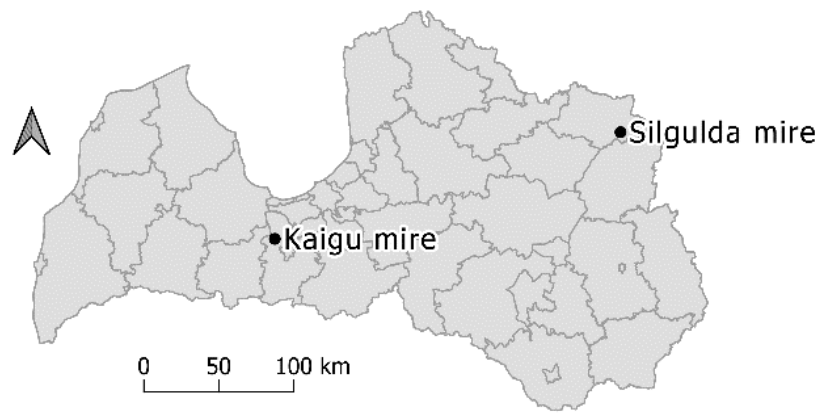

Figure 1. Location of Kaigu and Silgulda mires

\section{Field work}

Data on GHG emissions was obtained from abandoned and variously recultivated areas where peat was previously extracted. The main GHGs $\left(\mathrm{CO}_{2}, \mathrm{CH}_{4}\right.$ and $\left.\mathrm{N}_{2} \mathrm{O}\right)$ were measured once a month in each object containing five separately located measurement sites where four samples were taken per each site. In total, measurements were taken from 41 objects in a twoyear period from December 2016 to November 2018 (Lazdiņš, Lupiḳis, 2019).

GHG emissions were measured using closed chamber method. They are white, made of PVC. The chambers are $40 \mathrm{~cm}$ high, $50 \mathrm{~cm}$ wide (diameter) and their volume is 65 liters (Lazdiņš, Lupiḳis, 2019). Each object has 5 collars on which chambers are placed to make sure there is no air exchange with the surroundings. During the measurement, air released from the soil accumulates in the chambers. Total of 4 air samples are taken per a chamber during every sampling session (immediately after placing the chamber, at 20th, 40th and 60th minute), in total 24 sample sets per site (Lazdinšs, Lupikikis, 2019). 


\section{Data analysis}

Within the framework of the study, the type of recultivation of interest is afforestation, therefore data obtained from afforested peatland areas, as well as data from abandoned peat extraction sites (with and without vegetation), which served as reference territories, were used for data processing. To find any differences in emissions and the potential factors which determine them a comparison between these areas was made. Data processing and analysis was performed with the programs Microsoft Excel, PC-ORD 5, and Statistical Package for the Social Sciences (SPSS).

To sort the data required for the study for its further visualization and analysis Microsoft Excel was used. The necessary data was picked from the data set and sorted into smaller more compact tables. To obtain graphs which show the mutual regularities between the quantitative $\left(\mathrm{CO}_{2}, \mathrm{CH}_{4}, \mathrm{~N}_{2} \mathrm{O}\right.$ emissions, air temperature, soil temperature at $5,10,15$ and $30 \mathrm{~cm}$ depth, water table depth, area of both the peatland and the part of it that is degraded, thickness of the remaining peat layer, degree of decomposition of the upper peat layer) and qualitative (month, season and year and the weather conditions at the time of the measurements, land use) factors scatterplot function in PC-ORD 5 was used. To obtain graphs which show the trendline of correlating quantitative factors trendline option in Microsoft Office was used. To assess the main factors that determine the structure of the correlations and their influence on the overall variation of the factors, principal component analysis (PCA) was performed in PC-ORD 5. Graph Ordination function was used to visualize the axis of the PCA. To determine Pearson correlation coefficient between different quantitative factors IBM SPSS Statistics 22 was used. A correlation matrix was made there.

\section{RESEARCH RESULTS}

$\mathrm{CO}_{2}$ measurements were adjusted in all the areas with vegetation cover by multiplying all emission values with 0.5 , because as observed in a different project the emissions from peat without vegetation are $50 \%$ lower than from peat with vegetation cover, therefore, it is assumed that soil heterotrophic respiration is $50 \%$ of the total $\mathrm{CO}_{2}$ exchange. The reason for this is plant respiration (Aurela et al., 2007). The highest amount of $\mathrm{CO}_{2}$ was emitted from $>20$ years old Scots pine stands (2.8 $\mathrm{t} \mathrm{CO}_{2} \mathrm{ha}^{-1} \mathrm{yr}^{-1}$, Figure 2). Second highest value appears in $>20$ years old silver birch stands $\left(2 \mathrm{t} \mathrm{CO}_{2} \mathrm{ha}^{-1} \mathrm{yr}^{-1}\right) . \mathrm{In} \operatorname{area}$ afforested in spring of 2017 and area covered with herbs and dwarf shrubs the amount of $\mathrm{CO}_{2}$ emissions was the same $(1.9 \mathrm{t}$ $\left.\mathrm{CO}_{2} \mathrm{ha}^{-1} \mathrm{yr}^{-1}\right)$. The least amount of $\mathrm{CO}_{2}$ emissions was recorded in area not covered with vegetation $\left(0.9 \mathrm{t} \mathrm{CO}_{2} \mathrm{ha}^{-1} \mathrm{yr}^{-1}\right)$.

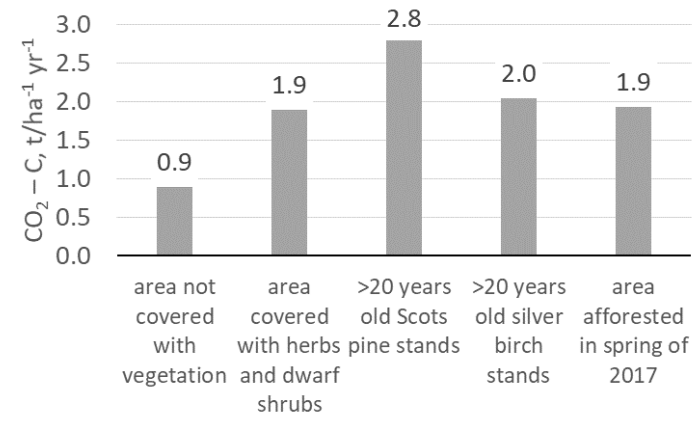

Figure 2. Net $\mathrm{CO}_{2}$ emissions

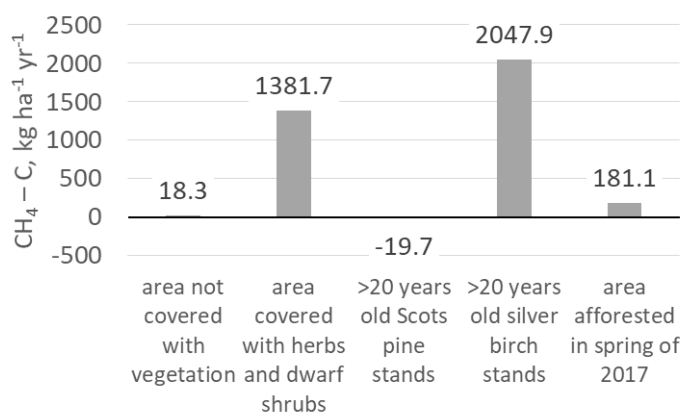

Figure 3. Net $\mathrm{CH}_{4}$ emissions, recalculated to $\mathrm{CO}_{2}$ equivalents

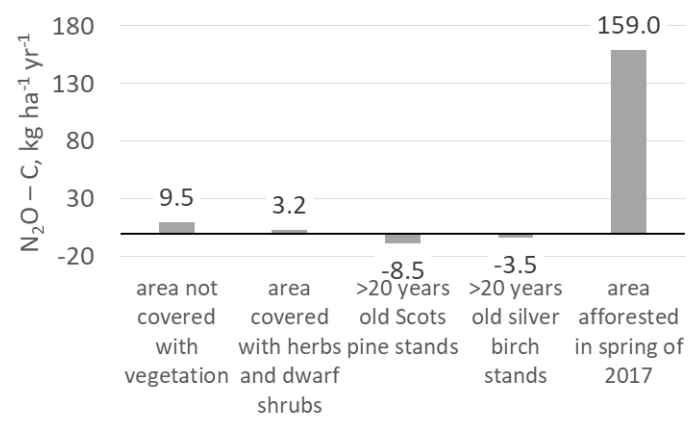

Figure 4. Net $\mathrm{N}_{2} \mathrm{O}$ emissions, recalculated to $\mathrm{CO}_{2}$ equivalents

According to the processed data average annual amount of $\mathrm{CH}_{4}$ emissions is the highest in the area afforested $>20$ years ago with silver birch Betula pendula (2048 $\mathrm{kg} \mathrm{CO}_{2} \mathrm{ha}^{-1} \mathrm{yr}^{-1}$, Figure 3). Significant amount of $\mathrm{CH}_{4} \mathrm{was}$ also emitted in the area with herbaceous and shrub vegetation (1382 $\mathrm{kg} \mathrm{CO}_{2} \mathrm{ha}^{-1} \mathrm{yr}^{-1}$ ). In all the other territories the amount of emitted $\mathrm{CH}_{4}$ was relatively low with even a slight sequestration in areas afforested $>20$ years ago with Scots pine Pinus sylvestris. As similar studies from around the world show the main factor that determines $\mathrm{CH}_{4}$ emissions is water table depth. 
Accordingly, the lower it is, the lower the methane emissions (Blodau, Moore, 2003; Dinsmore et al., 2009; Moore, Knowles, 1988). In the graphs obtained from data processing this regularity shows only partly. In $>20$ years old pine stand and area afforested in 2017 with various in the juvenile period fast-growing tree species water table is the deepest from all the considered territories (Figure 5) while at the same time emissions overall are low even showing a methane sink effect in the area afforested with Scots pine. In the birch stand and the area with herbaceous and shrub vegetation water table is shallow and methane emissions are high. The only territory where the regularity from literature does not show is extracted peatland without vegetation where $\mathrm{CH}_{4}$ emissions are low but the water table depth is near the ground surface. That could be explained with the absence of vegetation that reduces the activity of microorganisms (Lange et al., 2015; Ros et al., 2003). Sink effect in the pine stand could be explained with microorganisms which use methane as a source of energy in their metabolism (Lazdiņ̌̌, Lupiḳis, 2019).

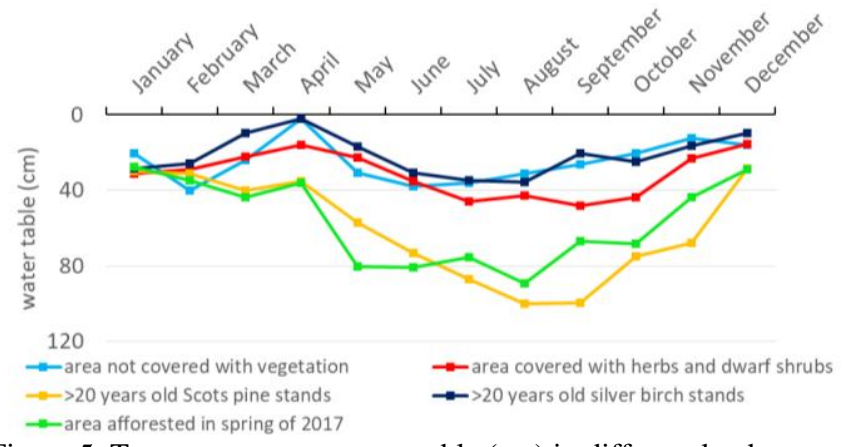

Figure 5. Two year average water table $(\mathrm{cm})$ in different land uses

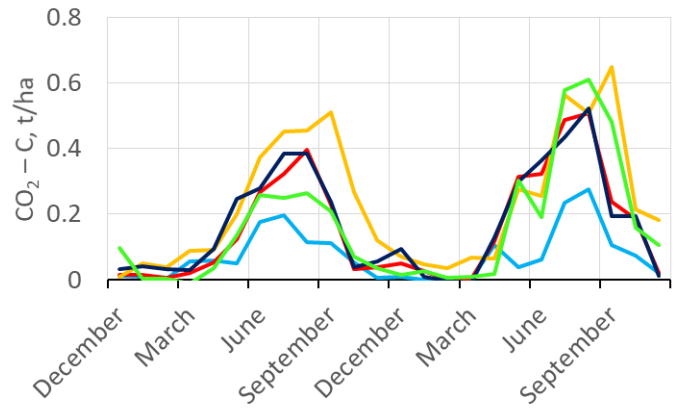

Figure 6. Monthly net $\mathrm{CO}_{2}$ emissions from December 2016 to November 2018

$\mathrm{N}_{2} \mathrm{O}$ emissions are the highest in area which is afforested in the spring of 2017 (Figure 4). In $\mathrm{CO}_{2}$ equivalents on average they are $159.0 \mathrm{~kg} \mathrm{ha}^{-1} \mathrm{yr}^{-1}$ which is significantly more than the amount emitted in other territories. The high amount of $\mathrm{N}_{2} \mathrm{O}$ there is determined by the usage of wood ash as a fertilizer which causes soil nitrogen to be released and become available to plants (Lazdina et al., 2019b). The emitted amount in all the other areas is remarkably lower. In the reference territories (area without vegetation and area with herbaceous and shrub vegetation) emitted amount of $\mathrm{N}_{2} \mathrm{O}$ is positive $(9.5 \mathrm{~kg}$ $\mathrm{CO}_{2}$ eq ha ${ }^{-1} \mathrm{yr}^{-1}$ and $3.2 \mathrm{~kg} \mathrm{CO}_{2}$ eq ha- $\left.\mathrm{yr}^{-1}\right)$. Opposite scenario appears in >20 years old pine and birch stands where $\mathrm{N}_{2} \mathrm{O}$ removals take place $\left(-8.5 \mathrm{~kg} \mathrm{CO}_{2} \mathrm{eq} \mathrm{ha}^{-1} \mathrm{yr}^{-1}\right.$ and $-3.5 \mathrm{~kg} \mathrm{CO}_{2}$ eq ha- $\left.\mathrm{yr}^{-1}\right)$.

It was observed that $\mathrm{CO}_{2}$ emissions are strongly correlating with soil temperatures, which corresponds to results from other studies (Ojanen et al., 2010; Salm et al., 2011). Therefore, the amount of emitted $\mathrm{CO}_{2}$ shows a seasonal trend during the two-year period (Figure 6). $\mathrm{CO}_{2}$ emissions were the highest in summer months and September when soil temperatures also reached their maximum values. In winter $\mathrm{CO}_{2}$ emissions are low and relatively homogenous (Figure 7 , Figure 8). As temperatures grow emissions also increase which is accompanied by a decrease in homogeneity of $\mathrm{CO}_{2}$ emissions. Correlation between soil temperature and $\mathrm{CO}_{2}$ emissions becomes stronger as the depth of the soil increases. The highest Pearson correlation coefficient $P$ was observed in 15 and $30 \mathrm{~cm}$ depths ( $\mathrm{r}=0.78$ for both) which is followed by $10 \mathrm{~cm}(\mathrm{r}=0.75)$ and $5 \mathrm{~cm}(\mathrm{r}=0.73)$ depths. $\mathrm{CO}_{2}$ correlation with soil temperatures show the same regularities as with air temperature although in all the viewed soil depths $P$ between soil temperature and $\mathrm{CO}_{2}$ was stronger than between $\mathrm{CO}_{2}$ and air temperature $(\mathrm{r}=0.68)$ (Figure 9).

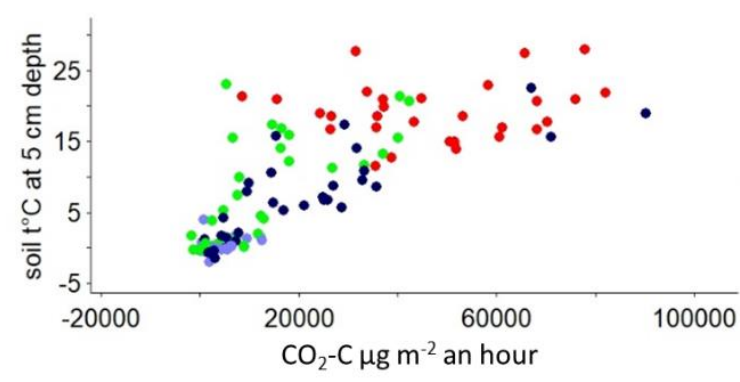

Figure 7. Correlation between soil temperature $\left({ }^{\circ} \mathrm{C}\right)$ at $5 \mathrm{~cm}$ depth and $\mathrm{CO}_{2}$ emissions ( $\mathrm{CO}_{2}-\mathrm{C} \mu \mathrm{g} \mathrm{m}^{-2}$ an hour)

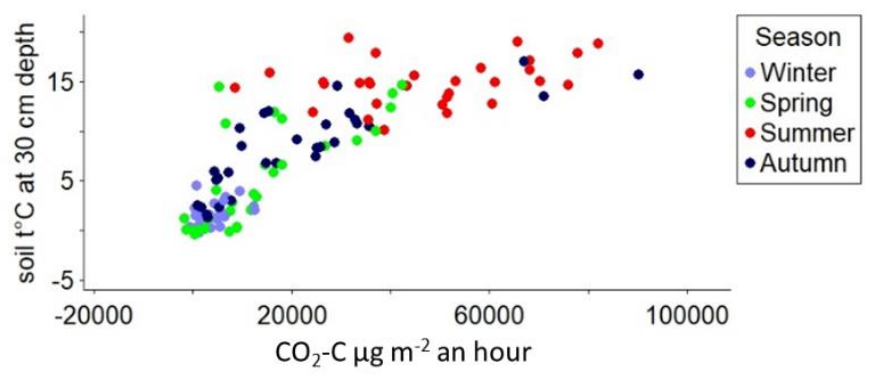

Figure 8. Correlation between soil temperature $\left({ }^{\circ} \mathrm{C}\right)$ at $30 \mathrm{~cm}$

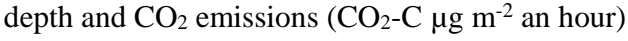




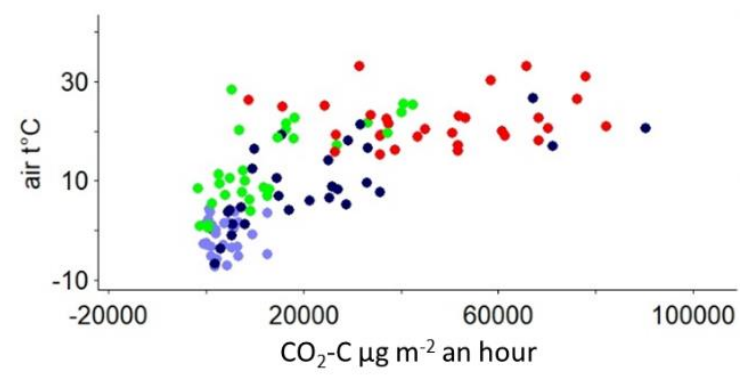

Figure 9. Correlation between air temperature $\left({ }^{\circ} \mathrm{C}\right)$ and $\mathrm{CO}_{2}$ emissions $\left(\mathrm{CO}_{2}-\mathrm{C} \mu \mathrm{g} \mathrm{m}^{-2}\right.$ an hour $)$

\section{CONCLUSIONS}

The study results prove that the most significant amount of GHG emissions from soil are $\mathrm{CO}_{2}$. These emissions in afforested areas are similar to the territory where herbaceous and shrub vegetation is growing but differ significantly from the area without any vegetation cover.

The strongest correlation with $\mathrm{CO}_{2}$ emissions was found for soil temperature - the higher the temperature the higher the amount of emitted $\mathrm{CO}_{2}$.

As the depth of soil increases the correlation between soil temperatures and $\mathrm{CO}_{2}$ emissions becomes stronger.

Significant seasonal differences in $\mathrm{CO}_{2}$ emissions were found in the study. During summer the highest GHG fluxes are observed, but during winter - the smallest. This can be explained by seasonal changes in soil temperature and this also points out that measurements of GHG fluxes during winter period are not necessary. However, significant increase of $\mathrm{N}_{2} \mathrm{O}$ emissions is observed in early spring, therefore should be measured more often than once per month or continuously.

Among the quantitative factors significant regularities that could explain the amount of $\mathrm{N}_{2} \mathrm{O}$ emissions in afforested areas were not found. To identify them, it may be necessary to carry out further research, supplementing forested and reference areas with other land uses, increasing the number of plots, as well as including additional factors such as soil chemical properties.

Acknowledgement. The article is elaborated within the scope of LIFE project "Demonstration of climate change mitigation measures in nutrients rich drained organic soils in Baltic States and Finland, LIFE OrgBalt", Grant agreement No. LIFE18 CCM/LV/001158.

\section{REFERENCES}

1. Aurela, M., Riutta, T., Laurila, T., Tuovinen, J.-P., Vesala, T., Tuittila, E.-S., Rinne, J., Haapanala, S., Laine, J. 2007. CO 2 exchange of a sedge fen in southern Finland-the impact of a drought period. Tellus B: Chemical and Physical Meteorology, Vol. 59(5), pp. 826-837. https://doi.org/10.1111/j.1600-0889.2007.00309.x

2. Blodau, C., Moore, T. R. 2003. Experimental response of peatland carbon dynamics to a water table fluctuation. Aquatic Sciences, Vol. 65, pp. 47-62. https://doi.org/10.1007/s000270300004

3. Dinsmore, K. J., Skiba, U. M., Billett, M. F., Rees, R. M. 2009. Effect of water table on greenhouse gas emissions from peatland mesocosms. Plant and Soil, Vol. 318, pp. 229-242. https://doi.org/10.1007/s11104-008-9832-9

4. Haghighi, T., Menberu, M. W., Darabi, H., Akanegbu, J., Klove, B. 2018. Use of remote sensing to analyse peatland changes after drainage for peat extraction. Land Degradation \& Development, Vol. 29(10), pp. 1-23. https://doi.org/10.1002/1dr.3122

5. Ji, F., Wu, Z., Huang, J., Chassingnet, E. 2014. Evolution of land surface air temperature trend. Nature Climate Change, Vol. 4, pp. 462-466. https://doi.org/10.1038/nclimate2223

6. Joosten, H., Couwenberg, J. 2009. Are emission reductions from peatlands MRV-able? Wetlands International, Ede. Available at https://www.wetlands.org/publications/are-emission-reductions-from-peatlands-mrv-ableae/

7. Kalniņa, L. 2019. Geology and stratigraphy of peatlands. In: Priede, A., Gancone, A. (eds.) 2019. Sustainable and responsible after-use of peat extraction areas. Baltijas krasti, Riga, pp. 55-80. Available at https://restore.daba.gov.lv/public/lat/jaunumi/117/

8. Krauklis, I. 1994. Kaigu purvs. Latvijas daba, Vol. 2. Riga, Preses nams, 207.

9. Krauklis, I. 1998. Silguldas purvs. Latvijas daba, Vol. 5. Riga, Preses nams, 93.

10. Krīgere, I. 2020. Development of Latvian peat industry over last 100 years. Folia Geographica, Vol. 18, pp. 71-81. https://doi.org/10.22364/fg.18.9

11. Lange, M., Eisenhauer, N., Sierra, C. A., Bessler, H., Engels, C., Griffiths, R. I., Mellado-Vazquez, P. G., Malik, A. A., Roy, J., Scheu, S., Steinbeiss, S., Thomson, B. C., Trumbore S. E., Gleixner, G. 2015. Plant diversity increases soil microbial activity and soil carbon storage. Nature Communications, Vol. 6, 6707. https://doi.org/10.1038/ncomms7707 
12. Lazdiņa, D., Lazdiņ̌̌, A., Bebre, I., Lupiķis, A., Makovskis, K., Spalva, G., Sarkanābols, T., Okmanis, M., Krīgere, I., Dreimanis, I., Kalniņa, L. 2019a. Afforestation. In: Priede, A., Gancone, A. (eds.) 2019. Sustainable and responsible after-use of peat extraction areas. Baltijas krasti, Riga, pp. 183-191. Available at https://restore.daba.gov.lv/public/lat/jaunumi/117/

13. Lazdina, D., Neimane, S., Celma, S. 2019b. Afforestation demo site. In Priede, A., Gancone, A. (eds.) 2019. Sustainable and responsible after-use of peat extraction areas. Baltijas krasti, Riga, pp. 208-220. Available at https://restore.daba.gov.lv/public/lat/jaunumi/117/

14. Lazdiňš, A., Lupiḳis, A. 2019. LIFE Restore project contribution to the greenhouse gas emission accounts in Latvia. In Priede, A., Gancone, A. (eds.) 2019. Sustainable and responsible after-use of peat extraction areas. Baltijas krasti, Riga, pp. 21-54. Available at https://restore.daba.gov.lv/public/lat/jaunumi/117/

15. LGIA. 2016. $6^{\text {th }}$ cycle orthophoto map of Latvia. Available at https://kartes.lgia.gov.lv/karte/ (accessed on 05/05/2021)

16. Moore, T. R., Knowles, R. 1988. The influence of water table levels on methane and carbon dioxide emissions from peatland soils. Canadian Journal of Soil Science, Vol. 69, pp. 33-38. https://doi.org/10.4141/cjss89-004

17. NRDC. 2019. Greenhouse Effect 101. Available at https://www.nrdc.org/stories/greenhouse-effect-101 (accessed on 06/09/2021)

18. Ojanen, P., Minkkinen, K., Alm, J., Penttila, T. 2010. Soil-atmosphere $\mathrm{CO}_{2}, \mathrm{CH}_{4}$ and $\mathrm{N}_{2} \mathrm{O}$ fluxes in boreal forestry-drained peatlands. Forest Ecology and Management, Vol. 260(3), pp. 411-421. https://doi.org/10.1016/j.foreco.2010.04.036

19. Parish, F., Sirin, A., Charman, D., Joosten, H., Minaeva, T., Silvius, M. (eds) 2008. Assessment on Peatlands, Biodiversity and Climate Change: Main Report. Global Environment Centre, Kuala Lumpur and Wetlands International, Wageningen. Available at http://www.imcg.net/media/download_gallery/books/assessment_peatland.pdf

20. Ring, M. J., Lindner, D., Cross, E. F., Schlesinger, M. E. 2012. Causes of the global warming observed since the $19^{\text {th }}$ century. Atmospheric and Climate Sciences, Vol. 2, pp. 401-415. https://doi.org/10.4236/acs.2012.24035

21. Ros, M., Hernandez, M. T., Garcia, C. 2003. Soil microbial activity after restoration of a semiarid soil by organic amendments. Soil Biology and Biochemistry, Vol. 35(3), pp. 463-469. https://doi.org/10.1016/S0038-0717(02)00298-5

22. Salm, J.-O., Maddison, M., Tammik, S., Soosaar, K., Truu, J., Mander, U. 2011. Emissions of $\mathrm{CO}_{2}, \mathrm{CH}_{4}$ and $\mathrm{N}_{2} \mathrm{O}$ from undisturbed, drained and mined peatlands in Estonia. Hydrobiologia, Vol. 692, pp. 41-55. https://doi.org/10.1007/s10750-011-0934-7 